\title{
THE LIFE STORY OF A RESILIENT UNDERPRIVILEGED YOUTH: MOTIVATION TO LEARN SOFT SKILLS
}

\author{
${ }^{1 \& 2}$ Yatela Zainal-Abidin, ${ }^{2}$ Rosna Awang-Hashim \& \\ ${ }^{2}$ Hasniza Nordin \\ ${ }^{1}$ Yayasan Sime Darby, Malaysia \\ ${ }^{2}$ School of Education and Modern Languages \\ Universiti Utara Malaysia, Malaysia
}

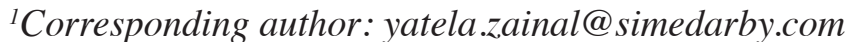

Received: 4 February 2018

Accepted: 6 May 2018

\begin{abstract}
Purpose - The study explored how an underprivileged blind individual from an extremely poor family developed resilience and soft skills to thrive in life, despite challenges that could have easily hindered the development of his abilities.

Methodology - This qualitative study employed the narrative inquiry method, involving responsive interviews. Experiences over a period of time were retrospectively documented via the collection of a life story from one participant who was very distinctive to the phenomenon being studied. Data analysis was carried out manually using open, thematic and longitudinal coding methods, after which interpretation was done to provide meaning to the results.
\end{abstract}

Findings - Positive youth development in the participant's life may be the result of the ecological system he grew up in, supported by three synergistic protective factors: religiosity and spirituality, parental discipline, and care and support, in addition to the traumatic life turning points he experienced.

Significance - The findings provide directions for further research on the underprivileged in the Malaysian context. They would also be able to guide the government and other interested stakeholders on potential methods and initiatives to build resilience and motivation to learn soft skills so that underprivileged children will be able to thrive in life. 
Keywords: Life story, narrative inquiry, resilience, soft skills, underprivileged, protective factors.

\section{INTRODUCTION}

Employers perceive soft skills to be more important for recruitment and long term employability than an individual's qualifications and hard or technical skills (Nickson et al., 2012; Robles, 2012; Seth \& Seth, 2013). A Harvard University survey (Robles, 2012) indicated that $80 \%$ of career achievements were determined by soft skills and only $20 \%$ by hard skills. Another study conducted among Fortune 500 CEOs by the Stanford Research Institute and the Carnegie Mellon Foundation found that $75 \%$ of job success in the long term depended on soft skills and only $25 \%$ on hard skills (Seth \& Seth, 2013). Aside from career needs, soft skills are also important to develop in children and adolescents, especially those from underprivileged and risky backgrounds, to address behavioural problems and/or reduce life or health risk factors such as smoking, drug and alcohol abuse, sexual activity and suicide (Jegannathan, Dahlblom, \& Kullgren, 2014; Tymes, Outlaw, \& Hamilton, 2016).

In Malaysia, youth face employability challenges due to the lack of required soft skills (Abdul Karim et al., 2012; Awang-Hashim, et al., 2015; Pillai, Khan, Ibrahim, \& Raphael, 2011; Zaharim, Ahmad, Yusoff, Omar, \& Basri, 2012). According to a press release dated 29 May 2012 on the website of the Economic Planning Unit (EPU) of the Prime Minister's department (http://www.epu.gov.my/en/s11m), tracer studies by the Ministry of Higher Education (MOHE) found that most of the $20 \%$ of graduates who did not secure employment within six months of graduation were underprivileged. According to the 2015 Graduate Tracer Study Report Ministry of Higher Education, 2016, 42\% of unemployed recent graduates were from families earning a monthly household income of RM1,000 and below, followed by $34.8 \%$ from families with a monthly income of between RM1,001 and RM2,000, and 27.1\% from families with a monthly income of between RM2,001 and RM3,000. As for the soft skills of graduates, the literature suggests that Malaysian tertiary education institutions should play a role in developing them, as these institutions provide the final level of formal education before 
graduates enter the workplace (Abdul Karim et al., 2012; Esa, Padil, Selamat, \& Idris, 2015; Idrus, Dahan, \& Abdullah, 2009 \& 2014; Musa, Mufti, Latiff, \& Amin, 2012; Nikitina \& Furuoka, 2012).

However, some studies have indicated that it would be wiser to address soft skill gaps among the underprivileged earlier, and that national policies should allocate early childhood educational resources for the underprivileged, rather than pay for interventions later in life, when the gaps are harder and more expensive to close (Garcia, 2015; Heckman \& Kautz, 2012). "Investing early allows us to shape the future; investing later chains us to fixing the missed opportunities of the past" (Heckman, 2011, p. 47). Henkman also pointed out that even though soft skills development is empirically proven to be important to drive life success, it is a neglected factor especially with regards to the underprivileged.

\section{Importance of Developing Soft Skills among the Underprivileged}

Heckman (2013) articulated that children who grow up in disadvantaged environments do not typically receive the same early enrichment as children from better families who devote more time to child enrichment activities. Garcia (2015) found that both hard and soft skills were least developed in the underprivileged and suggest that national policies and support programmes should be designed to assist the underprivileged, who begin their school life with comparatively less soft skills.

In the Malaysian context, the risk factors present in the lives of underprivileged individuals may increase the likelihood of a negative life outcome relating to the individuals themselves (drug and sexual abuse), their family (neglect), their school (detachment) and their community (discrimination), which may in turn lead to social issues, crime and poor performance in cognitive or academic tasks (Kuldas, Hashim, \& Ismail, 2014). According to Abdul Kadir et al. (2012), underprivileged youth in Malaysia face the risk of being involved in delinquent activities and dropping out of school. Yet, despite the life challenges that prevent the majority of these students from succeeding, some have been found to possess academic resilience. Unfortunately, empirical data on such cases remain scarce (Kuldas et al., 2014). 


\section{Protective Factors and Developmental Assets}

Protective factors and developmental assets comprise the experiences, opportunities, relationships, values and skills that young individuals require to improve themselves (Scales, 2011; Scales, Roehlkepartain, \& Shramko, 2016). Forrest-Bank, Nicotera, Anthony, and Jenson (2015) highlighted that studies have found that certain at-risk youth never participated in problematic behaviours because they had assets or protective factors, i.e., positive attributes of the individuals, families, communities and societies they lived in, that helped them become resilient. This is in tandem with the Search Institute's Development Asset framework which proposes that development assets may be used to predict soft skills, of which one is resilience. The framework also suggests that external development assets, or the experience, support and opportunity received by youths from the people around them play the main roles in resilience development (Scales et al., 2016).

A specific developmental asset found in the literature to develop resilience and thriving behaviours is religiosity and spirituality. A global research by Scales, Syvertsen, Benson, Roehlkepartain, and Sesma (2014) found that actively religious youth were about 39\% less likely to engage in high-risk behaviours such as drug abuse and violence, and about $26 \%$ more likely to display thriving behaviours such as leadership and high achievement. Krauss et al. (2014) found in their Malaysian study that religiosity was the most significant promotive factor of prosocial behaviours. Even though religion has been considered a prevention tool in reducing youth risky behaviours for decades, it is more recently seen as a life intervention to provide values, support, coping and resilience.

\section{Bronfenbrenner's Ecological Theory on Human Development}

Bronfenbrenner's ecological theory focuses on an ecological paradigm that explains how a child's environment influences his or her development. Bronfenbrenner explains that Lewin's theory of psychological fields shows that the ecological environment models comprise a set of nested structures, each one being inside each other, like a set of Russian dolls. Bronfenbrenner (1994) articulates that the theory's five models focus on the immediate environment a child lives in, such as family, peer group and school; the relationship between 
immediate environments such as the parent-teacher relationship; the relationship between immediate and non-immediate environments, such as the school-community relationship; the various environmental relationships with reference to belief systems and lifestyle; as well as changes that happen over time in the environment the child lives in, such as changes in family structure, socioeconomic status and place of residence.

According to this theory, proximal processes or enduring forms of interaction in the child's immediate environment motivate the learning of new skills and should primarily happen during childhood. They have a greater impact on more advantaged and stable environments throughout an individual's life course, as compared to underprivileged environments. Bronfenbrenner stressed that there should be more focus on implementing proximal processes within the life of underprivileged children; and on the duration, frequency and quality of the interventions for effectiveness.

\section{Resilience Theory}

According to Zimmerman et al. (2013), Resilience Theory focuses on positive youth development and provides a conceptual framework for studying and understanding why certain underprivileged youth grow up to be thriving adults despite being exposed to risk in their early lives. This theory focuses on enhancing protective factors rather than reducing exposure to risk.

Ungar (2012) studied 16 underprivileged individuals from five countries, aged 13 to 16 , who faced adversities in their lives and not only survived them, but thrived. Alvarado and Ricard (2013) described thriving as "a positive developmental trajectory focused on adaptive goals beyond survival" (p. 511) and demonstrated that underprivileged individuals can thrive with the right developmental assets. The authors propose that thriving has 15 theoretical markers in adolescents such as soft skills (openness and prosocial qualities) and external assets (friend, peer and family support).

\section{Convergence of the Two Theories}

Christensen (2010) highlighted that Bronfenbrenner's theory should include the element of 'resilience' as it facilitates the understanding 
of an individual's ability to have persistence, aspirations and purpose in life. However, Ungar $(2012 ; 2013)$ indicated that there is indeed a convergence of the two theories as he presented an ecological approach to the study of resilience, discussing studies on interactions between individuals and their social ecologies that assist researchers to understand the resulting resilience. Ungar hypothesised resilience as a social ecological construct and explained that change of individuals and environments cause the correlating factors for positive developmental outcomes for resilience to change as well.

\section{The Important Question}

Duncan, Magnuson, and Votruba-drzal (2014) stated that unlike higher income families, poor families encounter difficulties in developing their children due to economic stress, lack of resources to enrich children's learning experiences and having less time to nurture them. This argument may partially explain why the underprivileged in Malaysia lack the soft skills needed to be employable and succeed in life. However, an important question asked about the life of the extraordinary individual we studied was: "What happened in the participant's life which caused him to be different from other underprivileged young people, to be resilient and motivated to learn soft skills and thrive?"

As the participant came from an extremely underprivileged family, he would have undergone a life similar to others who are underprivileged, having received similar family, school and community support. However, why was the participant exceptionally different from others with the same background? If we could find some answers, we could use the knowledge to help underprivileged children develop their resilience to be motivated to learn soft skills over time, through various initiatives such as support, training or awareness programmes, and national policy improvements.

\section{METHODOLOGY}

As this qualitative study sought to explore experiences through the life story of an underprivileged individual during his childhood and youth, the narrative inquiry method was used. The founders of this approach, Clandinin and Connelly (2000), stated that "narrative 
inquiry is stories lived and told" (p. 20) and that the idea of life stories within narrative inquiry was inspired by Dewey's theory of experience (1938). The data of life experiences as the phenomenon (Clandinin \& Connelly, 2000) is collected for turning points, events and stories (Creswell, 2013) for interpretation (Marshall \& Rossman, 2016).

According to Zimmerman et al. (2013), longitudinal research facilitates the study of the timing of protective factor development for protection against risk, identifies the ages when certain promotive factors become important for development, as well as considers effects across an individual's ecological factors across time. The current study is a "retrospective" longitudinal study, as the following of the participant's experiences over a period of time was done retrospectively via the collection of stories over a set life period (Caruana, Roman, Hernández-sánchez, \& Solli, 2015). The study was aimed at filling the gap in a subject matter mostly studied using quantitative cross-sectional methods, especially in Malaysia.

\section{Data Collection}

Riessman (2005) stressed that the narrative inquiry approach is "not appropriate for studies of large numbers of nameless and faceless subjects" (p. 6), as the analysis of personal life stories requires laborious and painstaking efforts. Creswell (2013) found many examples within narrative inquiry which involved only one or two individuals as participants, which he recommends as one of the aspects of a good study. For this study, data was collected from one participant, Firdaus, who was very distinctive to the phenomenon being studied, via two interviews which were recorded and transcribed.

The interviews carried out to collect Firdaus' life story used the responsive interviewing technique (Rubin \& Rubin, 2012), where in-depth unstructured interviews were carried out to understand experiences from as far back as can be remembered, and to seek rich information using open-ended questions. As the completeness of his story would add to the value and accuracy of the data and interpretation (Creswell, 2013), the interviews were done in the Malay language. 


\section{Why Choose the Life Story of Firdaus?}

Firdaus' father was a retired army personnel earning RM725 monthly and his mother was a housewife. He was the fifth of eight children, two of whom were still attending school. Firdaus had problems with his eyesight from a very young age, and he became totally blind at the age of 14 . Nevertheless, Firdaus received awards for his personal achievements such as the Anugerah Khas Warga Istimewa (Special Citizen Award) from the University of Malaya in 2012. Other achievements in university included being appointed as director of Interaction Day with Volunteers, winning second place in a team in goalball at national level and being an active member of the College Action Committee for Disabled Students. In school, he was president of the Society of Disabled Students, the Goalball Club and the Inclusive Club. Firdaus was also active in sports during school, participating and winning gold and silver medals in various sprint races at state level.

Firdaus completed his Bachelor of Arts degree in Anthropology and Sociology at the University of Malaya, achieving a cumulative grade point average (CGPA) of 3.28. His undergraduate study was sponsored by a prestigious local scholarship provider, which was outstanding for a disabled student. Upon graduation, he was appointed as an administrative officer at the Careers and Counselling Section of the Student Affairs Department at his alma mater. At the time of study, he had commenced postgraduate studies at the same university, pursuing a Master's degree in Psychology, under another scholarship term. Anyone who has had a conversation with Firdaus, especially after knowing about his family background and his disability, would be extremely but pleasantly surprised by his positive outlook on life, his motivation, his self-confidence, his passion, and his charisma, which are also the soft skills required to thrive in life.

\section{Data Analysis}

Marshall and Rossman (2016) stated that "the process of bringing order, structure, and interpretation to a mass of collected data is messy, ambiguous, time-consuming, and fascinating" (p. 214). For this study, manual coding was done while field notes and analytical memos were progressively written, and when interviews were being 
transcribed, as recommended by Saldana (2013). Charmaz (2014) explains that coding is the most important connection between collecting and analysing data, resulting in emergent assertions or theory to define what the data means.

Open coding was used to see main ideas and patterns in the data (Marshall \& Rossman, 2016) by coding the transcribed interviews, field notes and analytic memos (Saldana, 2013). Theming the data (Saldana, 2013) was then carried out, when the codes and themes emerge from data analysis (Robson \& McCartan, 2016). This was followed by longitudinal coding where the data was reviewed thematically and comparatively through time (Saldana, 2013). Interpretation of the codes and themes was then carried out to provide meaning, coherence and linkage of the results to answer the research question (Marshall \& Rossman, 2016).

\section{Trustworthiness and Rigour}

Rubin and Rubin (2012) accept that it is neither possible nor desirable for both the researchers (in data interpretation) and their participants (in interview responses) to eliminate all biases and expectations, due to their own personal knowledge and experiences. Therefore, this study was designed to ensure trustworthiness and rigour by triangulation and member checking (Creswell, 2013; Guba \& Lincoln, 1989; Marshall \& Rossman, 2016).

To facilitate triangulation (Creswell, 2013; Guba \& Lincoln, 1989; Marshall \& Rossman, 2016), Firdaus' mother and teacher were interviewed as other data sources (Marshall \& Rossman, 2016). Field notes were drawn up after each interview to document findings in the storytelling to highlight notable issues for analysis or follow-up (Creswell, 2013), and analytic memos were updated, as recommended by Saldana (2013), to document "the emerging patterns, categories and subcategories, themes and concepts" (p. 41). For member checking, the findings summary was provided to Firdaus to obtain his feedback and insights before the report was finalised (Marshall \& Rossman, 2016). All data and processes were documented and maintained as an audit trail in a research journal (Creswell, 2013; Marshall \& Rossman, 2016).

Rubin and Rubin (2012) highlight that qualitative research is valued more for its capability to unearth new findings and answers, than 
on its generalisability. This is supported by Marshall and Rossman (2016) who claim that life stories studies have the potential to provide more sources of research questions to be answered in future studies.

\section{RESULT AND DISCUSSION}

Positive youth development in Firdaus' life appeared to have been supported by the ecological protective factors of care and support, discipline, as well as religiosity and spirituality teachings. These protective factors may have developed his resilience to learn soft skills to thrive in life. In addition, two life-turning events and epiphanies in Firdaus' life may also have contributed to his resilience to learn soft skills: one of them was becoming blind at the age of 14 , and the other was his father's sudden outburst when Firdaus was 17.

\section{Firdaus' Life: Prominent Experiences through Time}

Over the years, Firdaus' had achieved much in his life. However, with his achievements, he had also faced more and more adversities. The summary of the prominent experiences in Firdaus' life which may be related to his resilience and soft skills development is tabulated in Table 1 below.

\section{Table 1}

Firdaus' Prominent Experiences by Age

\begin{tabular}{cl}
\hline Age & Firdaus' Experience \\
\hline $6-12$ & $\begin{array}{l}\text { Gradual increase in confidence and other soft skills to take } \\
\text { up leadership roles from kindergarten to primary school. } \\
\text { He was more an observer and follower. }\end{array}$ \\
10 & $\begin{array}{l}\text { Confided in mother when fellow students were giving him } \\
\text { a hard time at school as he was close to girls and was } \\
\text { considered 'soft' or feminine. His mother advised him to } \\
\text { stop his participation in school activities to mitigate the } \\
\text { teasing. }\end{array}$
\end{tabular}




\begin{tabular}{|c|c|}
\hline Age & Firdaus' Experience \\
\hline 13 & $\begin{array}{l}\text { Sudden increase in confidence in Form One when he en- } \\
\text { tered secondary school. He took on leadership roles and } \\
\text { was involved in school activities. }\end{array}$ \\
\hline 14 & $\begin{array}{l}\text { Became blind and changed schools. Sudden expansion of } \\
\text { protective factors in his life in boarding school because } \\
\text { he effectively had another close 'parent' to look after him } \\
\text { and provide protective factors. }\end{array}$ \\
\hline $15-17$ & $\begin{array}{l}\text { Mother saw him change after he became blind and went to } \\
\text { boarding school; he was more hardworking with school- } \\
\text { work and became manly in nature. }\end{array}$ \\
\hline $15-17$ & $\begin{array}{l}\text { Did not confide in mother about problems with fellow } \\
\text { blind students who ignored him, gave him the cold shoul- } \\
\text { der and spoke bad things about him behind his back. In- } \\
\text { stead, Firdaus sought solace from God and found strength } \\
\text { to pull through these tough times. }\end{array}$ \\
\hline 17 & $\begin{array}{l}\text { Father's outburst, just before Firdaus sat for his Sijil Pela- } \\
\text { jaran Malaysia (SPM) national examinations. He took it } \\
\text { as a challenge to do well in his SPM, with the final objec- } \\
\text { tive of entering university as his father aspired. }\end{array}$ \\
\hline 17 - now & $\begin{array}{l}\text { The first and only one among his siblings to have a uni- } \\
\text { versity degree. }\end{array}$ \\
\hline
\end{tabular}

Firdaus described how poor his family was by providing examples of the hardships faced.

"We looked for school shoes thrown behind houses, picked them up and washed them to use. Because we did not have money to buy such things at the time. We collected thrown-away school shoes and bags and used them. We did not feel any embarrassment doing this, because that was how my mother taught us. We lived a modest and difficult life. We ate rice with margarine; that was how my mother taught us."

While he was going through school, Firdaus faced challenges with other students even though he participated in various activities and 
took on various leadership roles. In primary school, they teased him because he was somewhat effeminate and liked to interact with girls. However, he did have teachers who valued his contributions in school. In secondary school, other blind students appeared to be jealous of him as he became the first visually impaired Library Prefect and was the first blind student to participate in school clubs and activities. They gave him the cold shoulder, and this greatly affected him. However, he did have non-blind friends with whom he fitted in well, and teachers who provided him with care and support.

Firdaus' highest achievements occurred immediately after two important turning points in his life, which according to him, changed how he saw and lived his life. These were when Firdaus completely lost his eyesight and became blind, and when his father had an outburst.

In his storytelling, the individual whom Firdaus mentioned most was his mother, who appeared to have made the largest impact in his life. He also appeared sad about his father not spending enough time with the family as the latter was working most of the time and did not spare enough time to help his wife bring up their eight children. In her interview, Firdaus' mother also indicated that she had faced the difficulty of raising her children alone.

\section{Religiosity and Spirituality}

Firdaus' family is Muslim, and he and his siblings were all made to read the holy Quran after Subuh (dawn) and Maghrib (sunset) prayers every day by his mother. When there was no school, she would make them read the Quran from Subuh until sunrise. Hence, Firdaus completed reading the Quran five times. His mother also ensured that they performed prayers five times a day. She also encouraged fasting (refraining from food and water from dawn until dusk) from a very young age. During the fasting month of Ramadhan, they were made to spend their time at the mosque reading the Quran. His father sometimes gave short sermons at home after Maghrib prayers by reading from his religious books, and his mother liked to tell stories about the prophets. Firdaus also mentioned that he usually became the lead in prayers (imam) at home. He would volunteer to do so at school when opportunity arose. When his teachers realised his capability to lead prayers, they saw the potential in him to become a leader in other activities, particularly when he was in Form 1. 
"My mother was very strict. When we arrived home at $7 \mathrm{pm}$, and after we bathed, we were made to read the Quran. She was very strict about this, but when we were older and finished school, only then did we understand what mom was doing for us all this while, which was important to build our soft skills, and build our identity as human beings."

Firdaus' mother explained that by reading the Quran and performing prayers five times a day, her sons would become good human beings. She described that her sons did not stay out late like the other boys; they were never rowdy, and were well behaved and compliant. She believed that children without strong religious beliefs would talk back at and fight with their parents. She also said that Firdaus' teacher favoured Firdaus as he liked to read the Quran. Firdaus' teacher described Firdaus as one who would perform Subuh prayers with him without fail and would sometimes even lead the prayers.

Faith works as a stronger protective factor that successfully helps children adapt and cope with life adversities, in some cultures more than in others (Zolkoski \& Bullock, 2012). In Firdaus' case, religiosity and spirituality teachings from a young age appeared to have developed his resilience. At the integrated secondary school that he attended after he lost his sight, Firdaus felt very sad about how the other blind students were treating him. However, he did not confide in his mother or his teacher as he used to do when he was in primary school. Instead, he cried and confided in God.

“... I was ignored and treated badly, I spoke to Allah and I received strength. I do not know how, but I could face it. Now when I think about it, I felt very sad at the time but not to the extent of killing myself or blaming fate. At the beginning I could not see, and yes, I felt quite lost. But Allah brought me back on track, and it was because of the strong religious teachings in my development and identity."

When asked, both his mother and teacher stated that Firdaus did not encounter any major problems during his secondary school years. His mother even described that Firdaus flourished and bloomed when he was in the school for the blind, and he became more hardworking academically. 


\section{High Discipline Environment}

Firdaus had a very strict mother, who was fiercer than his father. However, he had a closer relationship with his mother than his father, as his father was not at home most of the time. Zolkoski \& Bullock (2012) stated that protective factors which develop resilience include family conditions such as responsive parents who are warm and loving yet firm, rational and consistent but not overbearing or controlling. However, in Firdaus' case, although his mother was warm and caring, she was also at times very strict and controlling, and Firdaus remembered the pain caused by her physical punishments.
"...which means she did not have to call us, she did not have to shout. She would just show us what she was going to use to beat us, and we would go home. Because we were afraid of what she had in her hand."

Surprisingly, the high discipline environment that Firdausexperienced in his childhood, with physical punishments being meted out, can be considered a protective factor in his life. Grusec, Danyliuk, Kil, and Neill (2017) explains that parents with a low socioeconomic status tend to exert more controlling discipline methods to ensure the child's safety as they come from risky environments, and strict obedience is crucial. In this situation, the child would perceive the high discipline environment as care and support, and will therefore be more compliant. Discipline delivered, even with physical punishment, in a positive teaching context is regarded by the child as acceptable, doing them good, and normative.

\footnotetext{
"Usually we do not like fierce people, but she was different as she was fierce because she was being our mother. We were beaten daily but we did not really feel the pain. Because it all became normal..... We received beatings every day, we cried for a little while, and when she went away, we would laugh as if nothing happened. It felt normal because we were very stubborn boys.... This was the way my mother taught us. She was hostile but it had a good impact on her children's development."
} 
Both Firdaus' mother and teacher expressed that Firdaus was a compliant boy, and usually did as he was told. His teacher revealed that Firdaus did not shirk from any tasks requested by his teachers, especially with prayers, and followed his teacher's advice. Grusec et al. (2017) mentioned that fearless children are more affected by parental warmth.

\begin{abstract}
"During the beatings, there was the feeling of hate. But after it was over, mother would call us "Come and eat!" and would hand-feed all of us together. She would beat us when she was angry but she never suppressed her anger ... . So, in the situation when we were stubborn, we would remember when our mother would cry when she beat us... . My father would beat everyone in the house irrespective of whose fault it was; that was his way. So, it was different with him. But after his anger cooled down, he would meet all his children after group prayers, and apologise while explaining why he had beaten us."
\end{abstract}

There appeared to be no trauma in Firdaus' storytelling about the physical punishments meted out on him. Instead, he seemed to be bragging about the strict rules his mother imposed at home; on doing house chores and on how he and his siblings learnt to cook, clean the house and wash their clothes from as young as six years old. Firdaus also appeared to have a strong sense of responsibility over his younger siblings, and he showed concern that his mother had now mellowed down and was not as strict on the two youngest siblings as she had been with him and the others. His youngest siblings were neither able to perform house chores nor complete reading the Quran even once, even though the younger of the two was already ten years old.

"For example, I iron all my shirts and trousers even though I am visually impaired. This is why I feel that the education my mother provided to me from before until today is positive, if you accept it as positive."

\title{
Caring and Supportive Environment
}

Firdaus saw the sacrifices made by his mother and described them. Although she did not check their schoolwork, she took him and his 
siblings to school herself, with three or four of them on her bicycle or motorcycle at the same time. Although the neighbours talked about how unsafe it was for her to do this, she had no choice but to continue to send her children to school this way. Her difficulties made him feel that success was an important milestone in life. Firdaus exhibited unconditional love for his parents, especially his mother, due to the sacrifices she had made for her children.

“... I see my mother crying while bringing us up with all the challenges she faced, and this is why I love her so much... this is why I love my mother so much, because she faced everything alone as my father was working most of the time."

With an upbringing surrounded by strong religious teachings, he believed that he would receive from God what he gave to his parents, be it happiness or sadness. He also believed that their prayers for him would always be answered, without exception. He added that his university degree and his achievements at work were all due to their prayers for his success, and he would tell them that his success was not for himself but entirely for them. Firdaus' mother mentioned that only he, and not her other children, would say this to her. Based on how he related his feelings, it appears that Firdaus felt much care and support from his parents.

"... it is enough just to show love to our parents, and God willing, He will provide us with success....."

Firdaus' mother recalled that she chartered a taxi for RM30 a day to send Firdaus to and from school during his SPM examinations, as his boarding school was closed. This amount spent on his transportation was substantial for her. She felt that he appreciated her sacrifices, and he had told her that he wanted to succeed because of her sacrifices for him. Firdaus' boarding school teacher related how he noticed that Firdaus had a supportive family. He believed that this was one of the main reasons for his success.

The teacher himself also provided a caring and supportive environment at the boarding school while Firdaus was there. He was physically present with Firdaus and a few other blind students every day, as he lived in the school compound. He ensured that Firdaus 
performed group prayers with him. He also took Firdaus and his friends out for school excursions, to experience things that seeing young boys would do, such as having fun at a waterpark or even abseiling. He sometimes cooked extra food so that the boys could have a homecooked meal. The teacher related how Firdaus learnt Braille exceptionally quickly even though he had become blind at 14. He had expected Firdaus to take a longer time to learn to read Braille because at that age, it would not have been easy for him to feel the Braille dots as his fingers would have hardened and become less sensitive. Yet Firdaus had grasped the basics and could read Braille within a month of instruction. The teacher was still in touch with Firdaus and would visit him now and then.

\section{Firdaus' Two Life Turning Points}

\section{First Turning Point: Becoming Blind at 14}

Firdaus became blind on 31 March 2005. He mentioned this date several times, as this extreme adversity was a significant point in his life. His mother described the time when he became completely blind as the most challenging time for him to come to terms with his fate. She had advised him not to be sad, and to be strong. Instead, he has cried, shouted and thrown tantrums because he was helpless - his whole world had turned dark. She had advised him to stop what he was doing and accept God's challenge. After a while, he began to accept his fate.

A month later, on 2 May 2005, Firdaus was transferred to an integrated school that had facilities for the blind. His teacher related that the other blind students in the school had been born blind, while Firdaus was the only student who had become blind as a teenager. As blindness came unexpectedly for Firdaus, his experience was different from the rest of the students. Firdaus' teacher noted past encounters with other students, where such an affliction was traumatic and stressful enough for the family or the victim in Firdaus' position, to have even led to suicide attempts.

It was Firdaus' first time staying in a boarding school, and away from his family. However, his mother recalled that it was at this time that Firdaus suddenly bloomed and flourished. She described Firdaus 
as becoming even more studious and hardworking, taking up many activities and leadership roles at his new school. In addition, while he had been considered quite the 'feminine' boy before, preferring to play with his eldest sister and other girl friends over his brothers and other boys, both Firdaus and his mother described him as becoming quite manly after he completely lost his eyesight. Both Firdaus and his mother also mentioned that he might not have entered university if he had not become completely blind, and they now considered this turning point in his life as a divine blessing from God.

"That's why I say that what had happened is a blessing. I am convinced that if I could see, I would not have become much."

\section{Second Turning Point: Father's Outburst when Firdaus was 17}

Firdaus' father's outburst happened just before he took his SPM examinations at the age of 17. Apparently, his father was disappointed by his older siblings who did not enter university, indicating that this was an important objective in life.

"Because he told us: "I am ashamed as none of my children have made it into university. One by one, they have tried and failed." After that, I felt really pressured as I was the one in Form 5 at the time and was just about to sit for my SPM examinations, and I was blind. I thought to myself that I had to do something and take this opportunity. What I mean is that my father had never become this angry before, and he had never expressed himself in this manner. Was he ever satisfied with his children's academic performance and achievements before this? And when my turn came, he had expressed himself like this. I then knew that I had to take this opportunity to prove myself to him and do the best that I could in my examinations."

It appeared that Firdaus felt a sense of pride that his father had chosen to bring up this matter and express his feelings when Firdaus was just about to sit for his examinations. This was because his father was usually too busy and was a person who liked to keep his thoughts to himself. Firdaus felt as though his father was challenging him, and 
he had to prove himself to his father. To this day, Firdaus is the only one among his eight siblings with a university degree.

\section{CONCLUSION}

This study focused on the protective factors and developmental assets which Firdaus had in his life. It examined how his developed resilience and other soft skills assisted him in facing challenges and adversities that came his way, which resulted in him thriving in life rather than succumbing to the hardships he had faced. Firdaus' achievements may be attributable to a strong ecological system comprising religious and spiritual teachings, parental discipline, and care and support; mostly implemented by his mother even though she had to raise her eight children mostly on her own.

These findings are consistent with both the Bronfenbrenner Ecological Theory and Resilience Theory, which converge and centre on enhancing protective factors through the understanding of individuals' interactions with their social ecologies, and also includes how a child's environment influences his or her development. In a social ecological system, each protective factor is interrelated and integrated with each other, as well as with the various life environments they are in.

The three protective factors found in Firdaus' ecological system are very much connected, and they should be analysed further in future to determine how they work together in synergy in the life of the underprivileged. Religiosity and discipline are based on a similar ideology of living within strict rules and parameters, where an individual is forced to or prohibited from doing something to internalise cultural values. A caring and supportive environment is critical to ensure that the intended positive and effective outcomes are the result of both religiosity and discipline implemented together. Although there are separate studies on care and support (Bronfenbrenner, 1994; Dai \& Heckman, 2013) as well as religiosity and spirituality (Krauss et al., 2014; Scales et al., 2014) as protective factors to build resilience and other soft skills in the underprivileged, more research could be carried out on parental discipline as a developmental asset within the ecological system for the underprivileged. 
This study challenges the understanding of power assertion in parental discipline. Various studies have argued that effective parental discipline does not involve intrusiveness or coercion but that child autonomy support would result in internalisation of values (Baumrind,2012; Pinquart, 2017; Smetana, 2017). They also contend that children would feel anger towards their parents when they are frustrated by strict rules and physical punishment, but would repress these feelings to buy parental acceptance, which leads to short term compliance but not long term value internalisation (Grusec et al., 2017). At the same time, Grusec et al. (2017) have also highlighted research findings that point to the importance of considering cultural differences when studying parental discipline with a focus on power assertion. This study has found that if the discipline and punishment meted out is seen by the child to be normative, fair, and a sign of effort and care by the parent to teach the child values, the effect of the parental discipline could be generally positive.

Firdaus experienced two life turning points which may have contributed to his achievements today, i.e., becoming blind when he was 14 years old, and his father's outburst when he was 17 . This may mean that substantially difficult life trials which present themselves in the life of the underprivileged that is already filled with adversity, may produce highly positive results. This is on condition that the protective factors within the ecological system are strong (ForrestBank et al., 2015; Ungar, 2013; Zimmerman et al., 2013; Zolkoski \& Bullock, 2012).

It is interesting to note that although his mother was the closest person to him and a confidant in times of need, Firdaus had only turned to God when he was at his lowest period in secondary school. This suggests that religiosity may be one of the strongest protective factors (Krauss et al., 2014) in an underprivileged individual's teenage years, if he is brought up in a home focusing on religious teachings and discipline, with a caring and supportive environment.

As Firdaus' mother almost single-handedly created the strong environment at home which facilitated the development of resilience and other soft skills which helped him to thrive, his mother's life story would also be interesting to explore in order to understand how she faced extreme adversity to raise such an exceptional child. 
The findings of the study raise new questions which may be answered by conducting more research on the underprivileged in Malaysia. The results would be able to guide the government and other interested stakeholders on potential methods and initiatives to build resilience and motivation to learn soft skills so that underprivileged children will be able to thrive in life.

"In the end, we'll all become stories" - Margaret Atwood.

\section{ACKNOWLEDGMENT}

This research was supported by Universiti Utara Malaysia (Grant Code S/O 15995).

\section{REFERENCES}

Abdul Kadir, N. B., Rahim, S. A., Abdul Mutalib, M. H., Wan Mahmud, W. A., Chong, S. T., \& Subhi, N. (2012). Development of the Self-report measures of assessing developmental assets among at-risk youth in Malaysia. Child and Adolescent Social Work Journal, 29(5), 391-407. http:// doi.org/10.1007/s10560-012-0267-z

Abdul Karim, A. M., Abdullah, N., Abdul Rahman, A. M., Noah, S. M., Wan Jaafar, W. M., Othman, J., ... Said, H. (2012). A nationwide comparative study between private and public university students' soft skills. Asia Pacific Education Review, 13(3), 541-548. http://doi.org/10.1007/s12564-012-9205-1

Alvarado, M., \& Ricard, R. (2013). Developmental assets and ethnic identity as predictors of thriving in Hispanic adolescents. Hispanic Journal of Behavioral Sciences, 35(4), 510-523. http://doi.org/10.1177/0739986313499006

Awang-Hashim, R., Hock-Eam, L., Yatim, B., Tengku-Ariffin, T. F., Zubairi, A. M., Yon, H., \& Osman, O. (2015). Estimating prediction model for early identificatoin of low employability graduates in Malaysia. The Singapore Economic Review, 60(4). DOI: $10.1142 / \mathrm{S} 0217590815500277$

Baumrind, D. (2012). Differentiating between confrontive and coercive kinds of parental power-assertive disciplinary practices. Human Development, (55), 35-51. http://doi. org/10.1159/000337962 
Bronfenbrenner, U. (1994). Ecological models of human development. In International Encyclopedia of Education, 3(2), (pp. 37-43). Oxford, England: Elsevier.

Caruana, E. J., Roman, M., Hernández-sánchez, J., \& Solli, P. (2015). Longitudinal studies. Journal of Thoracic Disease, 7(V), 537-540. http://doi.org/10.3978/j.issn.2072-1439.2015.10.63

Charmaz, K. (2014). Constructing grounded theory. Los Angeles, LA: SAGE Publications Ltd.

Christensen, J. (2010). Proposed enhancement of Bronfenbrenner's development ecology model. Education Inquiry, 1(2), 101110. Retrieved from http://www.education-inquiry.net/index. php/edui/article/view/21936

Clandinin, D. J., \& Connelly, F. M. (2000). Narrative inquiry : Experience and story in qualitative research. San Francisco, CA: John Wiley \& Sons, Inc.

Creswell, J. W. (2013). Qualitative inquiry \& research design : Choosing among five approaches. California, CA: SAGE Publications, Inc.

Dai, X., \& Heckman, J. J. (2013). Older siblings' contributions to young child's cognitive skills. Economic Modelling, 35, 235248. http://doi.org/10.1016/j.econmod.2013.07.003

Duncan, G. J., Magnuson, K., \& Votruba-drzal, E. (2014). Boosating family income to promote child development. The Future of Children, 24(1), 99-120. http://doi.org/10.1353/ foc. 2014.0008

Esa, A., Padil, S., Selamat, A., \& Idris, M. T. M. (2015). SoSTeM model development for application of soft skills to engineering students at Malaysian Polytechnics. International Education Studies, 8(11), 204-210. http://doi.org/10.5539/ ies.v8n11p204

Forrest-Bank, S. S., Nicotera, N., Anthony, E. K., \& Jenson, J. M. (2015). Finding their way: Perceptions of risk, resilience, and positive youth development among adolescents and young adults from public housing neighborhoods. In Children and Youth Services Review (Vol. 55, pp. 147-158). Elsevier Ltd. http://doi.org/10.1016/j.childyouth.2015.05.015

Garcia, E. (2015). Inequalities at the starting gate cognitive and noncognitive skills gaps between 2010-2011 kindergarten classmates. Washington, DC: Economic Policy Institute. Retrieved from https://www.epi.org/publication/inequalitiesat-the-starting-gate-cognitive-and-noncognitive-gaps-in-the2010-2011-kindergarten-class/ 
Grusec,J.E.,Danyliuk,T.,Kil,H.,\& Neill,D.O.(2017). Perspectives on parent discipline and child outcomes. International Journal of Behavioral Development, 41(4), 465-471. http:// doi.org/10.1177/0165025416681538

Heckman, J. J. (2011). The Economics of inequality. The Value of early childhood education. American Educator, 31-36. Retrieved from https://files.eric.ed.gov/fulltext/EJ920516.pdf

Idrus, H., Dahan, H., \& Abdullah, N. (2009). Challenges in the integration of soft skills in teaching technical courses: Lecturers' perspectives. Asian Journal of University Education, 5(2), 67-81. Retrieved from http://eprints.utp.edu. my/3358/2/challenges_on_integrating_SS.pdf

Jegannathan, B., Dahlblom, K., \& Kullgren, G. (2014). Outcome of a school-based intervention to promote life-skills among young people in Cambodia. Asian Journal of Psychiatry, 9, 78-84. http://doi.org/10.1016/j.ajp.2014.01.011

Krauss, S. E., Hamzah, A., Ismail, I. a., Suandi, T., Hamzah, S. R., Dahalan, D., \& Idris, F. (2014). Parenting, community and religious predictors of positive and negative developmental outcomes among Muslim adolescents. Youth \& Society, 46(2), 201-227. http://doi.org/10.1177/0044118X12464062

Kuldas, S., Hashim, S., \& Ismail, H. N. (2014). Malaysian adolescent students'needs for enhancing thinking skills, counteracting risk factors and demonstrating academic resilience. International Journal of Adolescence and Youth, 20(1), 32-47. http://doi.or $\mathrm{g} / 10.1080 / 02673843.2014 .973890$

Marshall, C., \& Rossman, G.B. (2016). Designing qualitative research sixth edition. California, CA: SAGE Publications, Inc.

Ministry of Higher Education, (2016). Laporan Pengesanan Graduan 2015. Putrajaya, Malaysia: Ministry of Higher Education. Retrieved from https://www.mohe.gov.my/muat-turun/awam/ statistik/190-laporan-kajian-pengesanan-graduan

Musa, F., Mufti, N., Latiff, R., \& Amin, M. (2012). Project-based Learning (PjBL): Inculcating Soft skills in 21st century workplace.Procedia-SocialandBehavioral Sciences,59(2006), 565-573. http://doi.org/10.1016/j.sbspro.2012.09.315

Nickson, D., Warhurst, C., Commander, J., Hurrell, S. A, \& Cullen, A. M. (2012). Soft skills and employability: Evidence from UK retail. Economic and Industrial Democracy, 33(1), 6584. http://doi.org/10.1177/0143831X11427589 
Nikitina, L., \& Furuoka, F. (2012). Sharp focus on soft skills a case study 2011. Educational Research for Policy and Practice, 11(3). http://doi.org/10.1007/s10671-011-9119-4

Pillai, S., Khan, M. H., Ibrahim, I. S., \& Raphael, S. (2011). Enhancing employability through industrial training in the Malaysian context. Springer Science+Business Media B.V., 62(5), 573-592. http://doi.org/10.1007/S10734-01

Pinquart, M. (2017). Associations of parenting dimensions and styles with externalizing problems of children and adolescents : An updated meta-analysis. Developmental Psychology, 53(5), 873-932. http://doi.org/http://dx.doi.org/10.1037/ dev0000295.supp

Riessman, C. K. (2005). Narrative analysis. In Narrative, Memory \& Everyday Life. University of Huddersfield, Huddersfield (pp. 1-7). Retrieved from http://eprints.hud.ac.uk/4920/

Robles, M. M. (2012). Executive perceptions of the top 10 soft skills needed in today's workplace. Business Communication Quarterly, 75(4), 453-465. http://doi. org/10.1177/1080569912460400

Robson, C., \& McCartan, K. (2016). Real world research fourth edition. London, England: Wiley \& Sons Ltd

Rubin, H. J., \& Rubin, I. S. (2012). Qualitative interviewing : The art of hearing data. California, CA: SAGE Publications, Inc.

Saldana, J. (2013). The coding manual for qualitative researchers. Los Angeles, LA: SAGE Publications Inc.

Scales,P.C.(2011). Youth developmental assets in global perspective: Results from international adaptations of the developmental assets profile. Child Indicators Research, 4(4), 619-645. http://doi.org/10.1007/s12187-011-9112-8

Scales, P. C., Roehlkepartain, E. C., \& Shramko, M. (2016). Aligning youth development theory, measurement, and practice across cultures and contexts: Lessons from use of the developmental assets profile. Child Indicators Research, 1-34. http://doi. org/10.1007/s12187-016-9395-X

Scales, P. C., Syvertsen, A. K., Benson, P. L., Roehlkepartain, E. C., \& Sesma, A. J. (2014). Relation of spiritual development to youth health and well-being: Evidence from a global study. In Handbook of Child Well-Being: Theories, Methods and Policies in Global Perspective (pp. 1101-1135). Springer. http://doi.org/10.1007/978-90-481-9063-8 
Seth, D., \& Seth, M. (2013). Do soft skills matter? - Implications for Educators based on recruiters' perspective. IUP Journal of Soft Skills, 7(1), 7-20. Retrieved from http://connection. ebscohost.com/c/articles/87710984/do-soft-skills-matterimplications-educators-based-recruiters-perspective

Smetana, J. G. (2017). Current research on parenting styles, dimensions, and beliefs. Current Opinion in Psychology, 15, 19-25. http://doi.org/10.1016/j.copsyc.2017.02.012

Tymes, D. D., Outlaw, K. L., \& Hamilton, B. K. (2016). Life skills interventions to improve social confidence, self-management, and protection against drug use in rural elementary school aged children. Journal of Community Health Nursing, 33(1), 11-9. http://doi.org/10.1080/07370016.2016.1120592

Ungar, M. (2012). The social ecology of resilience: A Handbook of theory and practice. New York, NY: Springer.

Ungar, M. (2013). Resilience after maltreatment: The importance of social services as facilitators of positive adaptation. Child Abuse andNeglect, 37(2-3),110-115.http://doi.org/10.1016/j. chiabu.2012.08.004

Zaharim,A.,Ahmad,I.,Yusoff,Y.M.,Omar,M.Z., \& Basri,H.(2012). Evaluating the soft skills performed by applicants of Malaysian engineers. Procedia - Social and Behavioral Sciences, 60, 522-528. http://doi.org/10.1016/j.sbspro.2012.09.417

Zimmerman, M. A., Stoddard, S. A., Eisman, A. B., Caldwell, C. H., Aiyer, S. M., \& Miller, A. (2013). Adolescent resilience: Promotive factors that inform prevention. Child Development Perspective, 7(4), 1-9. http://doi.org/10.1038/jid.2014.371

Zolkoski, S. M., \& Bullock, L. M. (2012). Resilience in children and youth: A review. Children and Youth Services Review, 34(12), 2295-2303. http://doi.org/10.1016/j.childyouth.2012.08.009 